\title{
THE QUEERNESS OF LOLLY WILLOWES
}

\section{Peter Swaab}

'If they were different from other people, why shouldn't they be?' Laura Willowes asks herself (Warner, 1926, p.129). Her thought is prompted by the sight of a group of women from Great Mop going off to what she doesn't yet know is a witches' sabbath. Laura might be voicing the motto for 1980s literary criticism. Vive la différence. But what sorts of difference does the book present us with? and does it give them an unequivocal welcome? What differences lead the witches of the world to unite in Great Mop? Lolly Willowes is clearly and at times polemically a story about gender, and above all about the expectations and experience of a certain gendered category, that of spinster. Should we see it also as a story about sexuality and sexual identity? In particular, should we interpret it as a story of homosexuality, drawing on our knowledge that Warner, although she was still in the mid-1920s involved in her long affair with Percy Buck, would in 1930 begin her lifelong relationship with Valentine Ackland? Some of these questions touch on Warner's biography, but my main intention in considering them will be to shed light on one of the most compelling matters prompted by Warner's amazing oeuvre, namely the interconnections between her radicalism in sexuality, gender and politics.

Few commentators on the book have considered it in this light. The notable exception is Jane Garrity, who includes an extended commentary on Lolly Willowes in Step-daughters of England (2003). Her essay is packed with subtle and illuminating suggestions, and is valuable 
too for its investigation of homosexuality in Warner's work outside the texts which most openly invite that approach: Mr Fortune's Maggot, Summer Will Show, parts of The Flint Anchor; certain poems ${ }^{1}$; such stories as 'A Long Night', 'Bruno', and 'A Love Match'; nonfictional work such as the translation of Proust and the biography of T.H. White. She candidly presents her interpretation as a polemical attempt 'to claim a lesbian specificity in conjunction with [Warner's] work', and as "a "perverse reading", a strategic lesbian-feminist appropriation of the text' (Garrity, 2003, p.149; p.151). We may then expect elements of polemical exaggeration, and it seems to me that some of Garrity's arguments are indeed strained: the idea for instance of Satan as a feminised figure ${ }^{3}$ (2003, p.174), or that the heroine's 'eroticised relation to nature' is intrinsically a same-sex one, with in the end 'an equivalence between homosexuality and nature' (2003, p.151; pp.178-9). 'When is a witch not a witch?', she asks: 'The answer, it may be argued, is when the witch is a lesbian' (2003, p.150). But this answer, to my mind, narrows and simplifies the conception of witchcraft in the book, and relies heavily on a possible analogy that supports the case only in some respects.

It seems to me that Lolly Willowes allows us to read both queerness and gayness in the text more directly and more variously than through the analogies of witchcraft and pantheism. We could for instance straightforwardly ask which of its characters might be understood as gay or lesbian. There is no shortage of candidates; perhaps queers like witches are 'as common as blackberries' (1926, p.234), to recruit Warner's touchingly natural and collectivizing simile.

We might begin with Laura's nephew Titus, down from Oxford in the winter of 1921.

Titus had a soft voice. His speech was gentle and sedate. He chose his words with extreme care, but escaped the charge of 
affectation by pronouncing them in a hesitating manner.

'I'm sure sculpture is his métier,' said Sibyl. 'Or perhaps poetry. Anyhow, not brewing. I wish you could have seen that little model he made of the grocer at Arcachon.'

Marion said: 'I thought bustos always had wigs.'

'My dear, you've hit it. In fact, that is my objection to this plan for making me a sculptor. Revive the wig, and I object no more. The head is the noblest part of man's anatomy. Therefore enlarge it with a wig.'

Henry thought the conversation was taking a foolish turn. But as host it was his duty to take part in it.

'What about the Elgin Marbles?' he inquired. 'No wigs there.'

The Peruke and its Functions in Attic Drama, thought Titus, would be a pretty fancy.

In his focus on the sartorial, his use of trivial, counterintuitive arguments, and his mockery of the idea of male nobility, Titus seems to be made in the mould of Algy from The Importance of Being Earnest; and indeed as an all-round Wildean exquisite he could give Brideshead Revisited's Anthony Blanche a run for his money. Warner tells us that we are in 1921, so we could just about imagine the two meeting at Oxford, Titus in his last year and Blanche in his first ${ }^{4}$. The aggregation of details about Titus in this passage makes for an overall effeteness which we may choose to attribute to the influence of 1920s Oxford, to the absence of a father figure in his life, - or, as the connotations invite, to his being gay. The soft voice, the gentle ways, the dainty affectations of speech (notwithstanding our narrator's escape-clause), the penchant for modelling male working-class foreigners, the Grecianism, the artsiness: we're given a catalogue of 
the lineaments of cultured male homosexuality of the period. In this scene Titus is the only one of his family to support his aunt's plan to go to Great Mop: as a presumptive queer he is Laura's natural ally. He seems to remain so until later, in a turn that is unexpected and painful, he becomes her worst obstacle. I shall return later to the significance of this surprising development in the story.

Other figures in the book, too, are in a variety of ways queer, in the sense of not fitting into the usual heterosexual familial structures or the expected gender roles. The book remains reticent about sexuality, but is nonetheless full of hints and indirections which cumulatively suggest that the world of sexuality in Lolly Willowes may be a wide one. So who else might earn a place in a gallery of the book's homosexuals? No other figure is so pointedly depicted as Titus, but the Willowes family genealogy is shot through with gaudy eccentrics and forebears whose marital and procreative histories remain unspecified ${ }^{5}$. Some of them, like Titus, fit uneasily into orthodox gender stereotypes. Laura's Aunt Emmy, for instance, just back from India, displays 'barrack-square trenchancy' (Warner, 1926, p.27), not unlike Bertie Wooster's redoubtable 'Aunt Dahlia' in P.G. Wodehouse. May we call her 'mannish', in the idiom of the day? She advises Laura to try her luck in the colonies, which Laura doesn't do, but the niece may be thought to renew the temper of her aunt's colonial excursiveness by bringing disgracefully exotic blooms back to Apsley Place. (In a small moment of female solidarity Caroline tempers their scandalous foreignness when she tells Henry they come not 'from Africa', as Laura had informed her, but 'from Anthos' (p.80) Hellenism being next to godliness.) Among the male Willoweses we have great-uncle (and Commodore) Demetrius, who was probably a warlock, as we discover in a deliciously preposterous moment (p.190). A generation further back we hear of 'great-great-aunt Salome', a pillar of church and state, but what should we make of her lurid biblical name? Or for that matter her 
father's? He is the first Titus we hear of, and he dates far enough back to suggest that he was named in fervid protestant tribute to Titus Oates. This Titus brought a green parrokeet back from the Indies, and the stuffed parrokeet with 'a rather leering look' resembles the author in 'surveying four generations of the Willowes family' (p.8) in enigmatic sardonic style.

The English gentry, we may infer, have always had room for eccentrics of one kind and another. There is a place, Warner suggests - there has long been a place - for such people in the established and conservative circles of English life. But perhaps the condition of membership of those eccentrics who are also homosexuals is an agreed discretion about what they are. They may signal their presence by connotations and intimations only, such plentiful but inexplicit connotations as I have been drawing out here. I would suggest that Lolly Willowes resembles both Mrs Dalloway (1925) and The Well of Loneliness (1928) as a 1920 s narrative about homosexuality in the English affluent classes. Each of the books naturalises homosexual proclivities as a feature of their well-established worlds, but shows the regulation of these worlds by sexual taboos. Clarissa Dalloway's Sapphic love for Sally Seton is a road not taken, so she can remain at the heart of London society and affiliated to the Westminster corridors of power. Stephen Gordon, on the other hand, goes the Sapphic way but it means leaving her father's house to live and love mostly abroad.

Laura's aunts and uncles are by kinship-based definition not in the main line of the Willowes family, but Warner also provides us with suggestively Oedipal narratives for Laura herself and her brother James. I suspect that the intimations that they are a daddy's girl and a mummy's boy knowingly partake of the Freudianism in British 1920 s culture $^{6}$. (Wendy Mulford notes that Warner remembered "sitting in a teashop after the war thinking about Freud, "as one often did at that period"..) $)^{7}$ James's intense attachment to his mother seems to mark him out as the non-marrying kind; even more so when after her death he does the unprecedented 
and unmasculine thing of moving some of her furniture into his own room, a detail which Warner notes in the dryly compassionate manner so particular to the book. James's elder brother Henry 'had taken it for granted that James would never marry' (Warner, 1926, p.34). However, not only does he marry, but he breeds too, against the familial expectations producing the male heir, Titus - who will in turn confound readerly expectations when he gets engaged to marry Pandora.

Laura, on the other hand, will not marry, and her attachment to her father matches James's to his mother. Warner gives us one especially charged spot of fatherdaughter time, a deeply sensuous vignette unusual enough to count for much in our sense of Laura's inner life.

She had always had a taste for botany, she had also inherited a fancy for brewing. One of her earliest pleasures had been to go with Everard to the brewery and look into the great vats while he, holding her firmly with his left hand with his right plunged a long stick through the clotted froth which, working and murmuring, gradually gave way until far below through the tumbling, dissolving rent the beer was disclosed.

This is a strange idyllic memory of trust and protection, as densely composed as the syntax is dense. It brings together alchemy and industry, dreaminess and productivity, in an innocently erotic sensuousness with intimations of both sexes, the stick and the stickiness.

If Warner laces the Willowes genealogy of the first section with hints of homosexuality, how does she follow through on this beginning? In particular, should we consider Great Mop as a haven for sexual dissidents under that motto 'If they were different from other people, why shouldn't they be?' (p.129)? There is a fair amount of evidence in this direction. To start with, Laura is prompted to go there by the florist who gives her some 
sprays of beech leaves 'From near Chenies, ma'am, in Buckinghamshire. I have a sister living there, and every Sunday I go out to see her' (p.86). No mention is made of either sibling's marital ties, with an intimation that they too belong in the book's community of the unmarrying. In Great Mop itself the non-patriarchal powers that be are two elderly sisters, the Misses Larpent. Like Celia and Justin in 'A Love Match', they are unmarried siblings living together; like Radclyffe Hall's Stephen Gordon, they are keen on their stable of horses. Also unmarried and sometimes feminised is Mr Saunter, placidly selfsufficient in his shell-shocked postwar life, a better darner of socks than Laura, 'mothering his chicks' (p.145) and apter at henwifery than Laura. Warner told William Maxwell that she drew for his character on her memories of her stepfather Ronald Eiloart as a young man (Steinman, 2001, p.145; p.220). I would suggest that he is also a precursor to the 'fatally sodomitic' (Maxwell, 1982, p.9) $\mathrm{Mr}$ Fortune of her next novel, to whom his name is trochaically related and even anagrammatically cousin (two letters off being a match). Even when we do encounter a married couple in Great Mop (the Leaks), $\mathrm{Mr}$ Leak so little troubles the narrative that he never appears anywhere it takes place. Among the other sexually indeterminate singletons there is the masked young man seen at the Witches' Sabbath 'mincing like a girl' (Warner, 1926, p.200) ${ }^{8}$. Laura at first takes this stranger for Satan himself, but his exotic glamour is not the real thing; he is a friend of Titus, Satan informs her (p.241), pledged to the devil in return for weekly occasions in which he will be the centre of attention. During the dance he licks Laura's right cheek close to her ear, which confirms that a polymorphous sexual licence is part of the deal. This is the kind of thing that made Laura hate parties before she became a witch, and it is an excellent touch that she feels the same distaste for this supernaturally sanctioned one. Being a witch doesn't transport her into an entirely different world, nor is it a portal to orgiastic pleasures sanctioned by the occult world. 
But the Witches" Sabbath does also include one compelling moment of sensuality:

Laura liked dancing with Emily; the pastyfaced and anaemic young slattern whom she had seen dawdling about the village danced with a fervour that annihilated every misgiving. They whirled faster and faster, fused together like two suns that whirl and blaze in a single destruction. A strand of the red hair came undone and brushed across Laura's face. The contact made her tingle from head to foot. She shut her eyes and dived into obliviousness - with Emily for a partner she could dance until the gunpowder ran out of the heels of her boots. (pp.192-3)

Emily is like a Blakean oxymoron, combining the anaemic pallor Blake despised with the red-haired fervour he extolled. Moreover, she is the sexton's niece as well as looking good on the dance-floor.

There is no other sexy moment like this in the book. On this evidence, Laura's physical thrills are same-sex ones. But the language here seems to me to be touched by parody, on the borderline between D.H. Lawrence and Stella Gibbons: "two suns that whirl and blaze in a single destruction'. The raised temperature of the simile cools off in the next sentence with rueful bathos: 'Alas! this happy ending was not to be, for at the height of their performance Emily was snatched away by Mr. Jowl, the horse-doctor' (p.193). It is hard to be an authentic sensualist when your name is Mr. Jowl. Warner's dry manner is comically sceptical about the importance of sexuality in human life. And indeed the novel as a whole has little interest in sexual fulfilment or even in romantic love. Most of the figures I have discussed, whatever their hinted proclivities, remain uncoupled and not noticeably troubled by their singleness. It is an audacious unconventional generosity in Warner's novel to suggest 
that for many people a happy ending may be a solitary one.

We might compare 'But at the Stroke of Midnight' (1967), (Warner, 1971, pp.35-77) the great story in which Warner rethinks many elements of Lolly Willowes, forty years on. In that story, Lucy Ridpath's escape from her unfulfilling domestic world is routed through a perfunctory sexual encounter in London with an unnamed man in whom she is not greatly interested. It is related with a lack of affect on her side that might remind us of Jane Bowles or Denton Welch. Their brief affair has only a brief place early in the story - this in the 1960 s context of another wave of heightened hopes that, as Blake put it, 'an improvement of sensual enjoyment' (1977, p.188) would lead to the palace of wisdom. But it doesn't do so here. Lucy achieves freedom of a kind, in a rural retreat more solitary than Laura's and lacking Great Mop's supernatural apparatus and community, but it has little to do with sexuality. Nonetheless, in this story too there would be some possible grounds for inferring Lucy's lesbian proclivity as well as her dissatisfaction with heterosexual marriage: her most powerful emotions seem to be her love and admiration for her free-living cousin Aurelia. As in Lolly Willowes, Warner's narrative seems on cordial terms with this intimation of unconforming sexuality, and to welcome its rebellion against maritally imposed drudgery; but again as in Lolly Willowes the story does not conceive of happiness in terms of sexual fulfilment.

Like Laura, Lucy has a feline companion. But unlike Laura she invests her love and sense of identity in the cat, naming it 'Lucy' after her former self and renaming herself 'Aurelia' after the cousin whose death precipitated her own escape. In this new life her affection is routed into animal companionship, described with great poignancy. Warner's description of the cat's death is shattering - and it shatters Lucy's new life. Lucy's intimacy with her cat and her estrangement from humanity are more emphatic than Laura's, but several of the most touching moments (literally) in Lolly Willowes 
also describe the contact not between human beings but between human beings and other creatures. For instance, 'Miss Jane would go round the stables and feel the horses' legs, her gnarled old hand with its diamond rings slipping over the satin coat' (Warner, 1926, p.120): a textured idyll, not just the dry hand and the sheen of the coat, but the harder surfaces of the rings too. Or take this other beautiful evocation, after $\mathrm{Mr}$ Saunter has taught Laura some of the arts of the henwife:

she managed them well enough to give herself a great deal of pleasure. They nestled against her, held fast in the crook of her arm, while her fingers probed among the soft feathers and rigid quills of their breasts. She liked to feel her acquiescence, their dependence upon her. She felt wise and potent.

(p.146)

How tactile that probing of the softness and the rigidity of the feathers, with its contrasting sense of another life, so very alien yet acquiescent too. Perhaps we are to remember the scene of childhood where Laura was held fast in the crook of her father's arm. As henwife she is able to take the place of a parent to her own liking. She has 'a great deal of pleasure', which Warner never shows her experiencing as guardian to the nieces and nephews in her charge.

One of her nephews is Titus, who follows her to Great Mop, out of affection and affinity as we may at first think. But it becomes clear that he has to go; the story takes a decisive view of his masculine failings as he pesters Laura and reinstates her as a family subordinate, asking for her advice and culinary help and shaping up to require her secretarial services for his Fuseli book. His attachment to the countryside is a discrediting parody of her own, a nostalgic and conservative ruralism to set against her own darker and less acculturated mysticism, as Mary Jacobs has shown in an excellent article on 'Sylvia Townsend Warner and the Politics of the English 
Pastoral 1925-1934' (2006, pp.61-82). Whereas $\mathrm{Mr}$ Saunter is 'a born countryman' (Warner, 1926, p.141) and Laura a born but displaced countrywoman, Titus was brought up in the city and his rusticity is another of his affectations. But the main wedge driven between aunt and nephew is not the country/city difference ${ }^{9}$, but the category of gender. Although Titus, like his aunt, loves the landscape of the area, his 'was a reasonable appreciative appetite, a possessive and masculine love' (p.160), whereas hers was a gamble and a recognition; 'at intervals Titus would stop and illustrate the landscape with possessive gestures' (p.214). His possessiveness as 'loving nephew' (p.179) is pointedly juxtaposed to Satan's 'indifferent ownership' (p.247) as 'loving huntsman' (p.177). Titus's offensively masculine sense of entitlement is confirmed and consummated when he announces his engagement to Pandora. He does so on the same day as Satan at Laura's behest finally drives him out of Great Mop. He is banished from Great Mop, it seems, when he embraces heterosexuality, if this is indeed what his marriage may be thought to entail. But perhaps this is putting the terms of their engagement more decisively than Warner chooses to do. She frames it more widely as something beyond the consenting parties, as a reestablishment of dynastic orthodoxy: 'at the back of her mind Laura felt that Titus was but a proxy wooer, the ambassador of an imperious dynastic will; and that the real match was between Pandora and Lady Place' (p.223).

We may then see Great Mop as a queer refuge, in which Laura finds sanctuary and from which Titus is banished when he joins up to the marrying and patriarchal classes. But how far should we see Great Mop in utopian terms? Just how good a place is it? Gillian Beer has described Warner's work as

at once sceptical about belief and wholehearted in its relish of the possible. The Utopian reach of her fictions of the 1930 s is, over and over again, undermined sardonically from within. $\quad(2004$, p.18) 
I have suggested that some such undermining limits the few intimations of sexuality in Lolly Willowes. Should we also see the depiction of Great Mop as hedged around with scepticism?

Perhaps the place to start is class. The village is not freed from class constraints by its supernatural endowments. The elder Miss Larpent reduces her domestics to tears when she finds fault with their standards of service. She and her sister preside from their great house in feudal style. Mrs Leak's solidarity with her fellow-witch Laura yields when Titus visits: she defers to both alike as 'gentry'. The village may be hospitable to witches, but the pacts with the devil do not seem to herald a new social order: its social demarcations, indeed, are rather old-fashioned. Fraternity and comradeship seem a long way off, with the main expression of solidarity being the conspiracy of silence among the practitioners of the dark arts. This suits Laura perfectly well, since she is not very political; early in the book (the setting is 1902) she imagines 'processions of the Royal Family and of the unemployed' without apparently seeing any category difference between these 'exciting' spectacles (p.4). We can get an idea of what she refers to from a contemporary reminiscence of the London of 1902-03, in Jack London's 'Author's Preface' to The People of the Abyss (1903):

To such an extent did the suffering and positive starvation increase that society was unable to cope with it. Great numbers of the unemployed formed into processions, as many as a dozen at a time, and daily marched through the streets of London crying for bread ${ }^{10}$.

(pp.297-8)

Is Laura to blame for her naivety about such desperate hardship? She has grown up in Somerset, far from public life, and is recently bereaved, which may extenuate the fault; and in general the narrator abstains from overtly finding fault with Laura, leaving that to her relatives. But 
still, Lolly Willowes was published in February 1926, in the months leading up to the General Strike of May that year, so the hardship of workers and unemployed was both urgent and topical when Warner wrote the book. British seamen had gone on strike in 1925, and the cutting of miners' wages in June 1925 gave strong indications of further workers' protests to follow. The allusion to the unemployed shows some of Laura's limitations; she is and remains partly the daughter of her sublimely torpid mother, with 'a temperamental indifference to the need of getting married - or, indeed, of doing anything positive' (p.26).

Laura's political consciousness evolves during the book, to the point where she sees her own oppression as inextricably connected to the whole apparatus of Western capitalism (p.150); but quietude remains powerfully attractive to her, and if Great Mop is a utopia, it is far from an activist one. It is subtly unclear how far Laura and the narrator take the same view about the appeal of quiescence. The voices of the two merge for the first time in a gnomic utterance on the brink of Laura's departure from London: "It is best as one grows older to strip oneself of possessions, to shed oneself downward like a tree, to be almost wholly earth before one dies' (p.106). This placid dendrophile wisdom seems at first to be Laura's resignation about Henry's mismanagement of her funds, but it shades into a wider perception endorsed or offered by the narrator. A few pages later we see Laura approach closer to this vegetable ideal:

On the following morning she fell asleep again, in a beech-wood, curled up in a heap of dead leaves. After that she had no more trouble. Life becomes simple if one does nothing about it. Laura did nothing about anything for days and days till Mrs Leak said: 'We shall soon be having Christmas, miss'. 
But how far is it an ideal? Falling asleep in the wood has its idyllic side, and having 'no more trouble' is appealing up to a point, but 'Life becomes simple if one does nothing about it' is to my ear shaded with irony. Imagine it as the motto of a fortune cookie: is it a platitude or a key to living? The following sentence, beginning 'Laura did nothing about anything for days and days', doesn't sound too impressed: this is the simple life of blank inaction, and Laura has to be brought back to consciousness by Mrs Leak. Warner's narrative never decisively dissociates itself from Laura, and the warmth and clarity of the book come from its siding so loyally with her. Therefore, if this is what Laura wants, so be it; the idea of witchcraft in the book is anarchistic in the respect that each person's pact with the devil is tailormade for his or her own nature. Nonetheless, although Laura tells the devil that women become witches 'to show our scorn of pretending life's a safe business, to satisfy our passion for adventure' (p.238), her own is a reclusive and unexuberant plan of happy life, 'rooted in peace' (p.150). Her inaction is radical, and the book moves her towards an unfretful contentment with what she is. Her desires are ultimately expressed in natural and even mystical terms and directed to a kind of union with the earth, bringing with it peaceful intimations of death, as Charles Prentice at Chatto noted when he asked her to revise the ending to make it less morbid (Harman, 1989, p.62)" . We might be reminded of "Stay Corydon, thou Swain"' (2001, pp.59-70), another of Warner's 1920s stories in which a main character (Miss Cave) disappears into nature, at the end literally vanishing away as she enters a wood. The book grants Laura what she wants, but doesn't press her into socio-political exemplariness. Laura was after all born in 1874, a generation before her author (1893), and she has a difficult family heritage to deal with; like Woolf's Mrs Ramsay in To the Lighthouse, she can go only so far towards realising a 1920s conception of sociompolitical progress. This is partly because of Laura's quietude, but partly it reflects Warner's decision that the ending of the novel should take 
place at some distance from the constraints of realism, in a fictional space where patriarchal injustices to women can be significantly redressed without a larger revolutionary transformation of society.

Great Mop has a village shop, a pub, a church and a population of 227 . We see little of its male inhabitants, and not much is made of their economic circumstances. It is not a merely fantastical utopia - the details of village life are too lively and specific for that - but nor is it explored in relation to modernity and the conditions of labour. It is hardly a site for revolutionary change. Warner's later fictions would give more materialist grounding to their locations. Tenorio Viejo in After the Death of Don Juan (1938) is hardly bigger than Great Mop, but the dramas staged there are microcosms of social upheaval on a wider canvas. Love Green in Opus Seven (1931), despite its pastoral name, is grittier. Geographically Great Mop is cut off from the world: it stands at the head of a valley, not on the way anywhere, five miles from the nearest village. But it is not entirely cut off, as it is also easily reachable from London and a railway line runs nearby. Its location in respect of realism is similarly remote but not decisively separate.

The village figures, then, as a place of escape, not as the seedbed of future change. We hear of no traffic between Great Mop and nearby settlements. There seems to be no danger that its secret will be discovered by the outside world - this despite the history of persecution and detection around witcheraft in England and Scotland. The immunity (from public detection, though not from familial interference) becomes apparent if we compare Lolly Willowes with Warner's famous story of sibling incest, 'A Love Match' (1961) (Warner, 1988, pp.1-20), which so much concerns the resourcefulness and intelligence needed to lead a life on terms unapproved by the world. Celia and Justin, incestuous siblings, devote much artistry and subtlety to keeping themselves private, for instance buying an otherwise unappealing house for the sake of its walled privacy. The story relishes the skills of the closet as well as counting its costs, but despite their 
best efforts Celia and Justin are threatened by rumours and dangers. Laura's destination may be a dubious utopia, but it is more securely removed from the threat of exposure. People in Great Mop aren't that interested in each other. They are allowed to be private.

Women become witches to have 'a life of one's own' (p.239), Laura says, and the affinity between Lolly Willowes and A Room of One's Own (1929) has been noted by more than one commentator (e.g. Harman, 1989, p.64; Beer, 2004, p.18). Warner had read Mrs Dalloway in 1925 , and was captivated by Woolf when they met: 'She is so charming that I had the greatest pleasure in stifling my scruples and telling her how much I admired it' (letter to David Garnett, 16 June 1925, in Garnett, R., 1994, p.6). (She expressed these scruples about Mrs Dalloway to Garnett in the form of a question: 'What is the use of describing feelings and thoughts, however vividly, if they are all to remain the author's?') Did Woolf read Lolly Willowes? and if so, did she make use of it in $A$ Room of One's Own? Her diaries and correspondence do not mention Warner's novel, but she noted their encounter in June 1925. 'At dinner met Miss Warner, the new Chatto \& Windus poetess, and indeed she has some merit - enough to make me spend 2/6 on her, I think' (Woolf, 1980, p.26). Cordial enough, though rather seigneurial, and perhaps Woolf would have taken note of her new acquaintance's éclat as a best-selling novelist when Lolly Willowes was published the following year. Some of its phrasings strikingly anticipate $A$ Room of One's Own.

From the start Lolly Willowes concerns possessions and possessiveness, in such pointed formulations as 'Henry and Caroline are to have you' (Warner, 1926, p.5) - Henry, that is, 'and Caroline his wife' (p.3) - and in historical reflections such as this one from Laura's niece's husband in around 1921: "The position of single women was very different twenty years ago," answered Mr. WolfSaunders. "Feme sole, you know, and feme couverte, and all that sort of rot."' (p.6). The legal history of this phrase goes back to Norman law, as the archaic spelling of 'feme' intimates: it means the provision by which only 
unmarried women were legally considered entitled to rights of ownership. Upon marriage a woman was thought to be 'covered', couverte, by her husband; he was sole owner of everything, an injustice which robs the heroine of Summer Will Show of her worldly goods ${ }^{12}$. Mr WolfSaunders is hardly a progressive spirit, but he can from the modernity of the 1920 s look back to these oppressive dispensations as 'all that sort of rot'. Lolly Willowes brings Laura to a recognition of what is rightly hers, and has recourse at several crucial moments to the phrase 'of her own' or 'of one's own'. 'Nothing is impracticable for a single, middle-aged woman with an income of her own" (p.102), Laura tells Henry, in a speech which may have lodged in Woolf's mind. Laura's rightful income of five hundred pounds a year (Woolf's prescribed amount) turns out to have been halved by Henry's arrogant mismanagement; it is a clever touch how little difference this finally makes, in that the worldly version of her happy independence (a cottage and donkey) isn't for Laura the heart of the matter. Instead of buying a cottage, she goes instead to lodge with Mrs Leak, where her predecessor in a liberating continuity of witch-aunts had also been 'an aunt with means of her own' (p.109). Not her own property but the village and its surrounds become 'her domain' (p.174). The final words of Warner's book, paradoxical but resolved, are 'profoundly indifferent ownership' (p.247).

Of all Warner's novels, Lolly Willowes is the most essayistic and - especially in its final pages - the closest to polemic, and the affinities with Woolf's seminal work are striking. This is the moment when the lives and works of the two greatest English women novelists of the century (for some of us) come closest to meeting. Nonetheless, Lolly Willowes achieves its ends as a work of fiction whereas A Room of One's Own is a series of essays, and it is in these terms that we might finally contrast the existential aspiration to 'a life of one's own' (Warner, 1926, p.239) with the practical desire for 'a room of one's own'. The room of one's own might help one to get a life or a career, but the life that suits Laura is 
not for everyone or even everywoman and it is something other than a career.

Warner tended in later life to be harsh about Lolly Willowes. In 1932 she called it 'thick-ankled', presumably implying that its didactic designs were too palpable (Maxwell, 1982, p.19). In her last years she suggested that the way to be marketable was to 'recapture the Lolly manner, and be light and satirical, and talk of ladies and gentlemen' (Mulford, 1988, p.33 citing Antonia Trauttmansdorff's unpublished memoir of Warner). Here she was herself recapitulating the reaction of some early admirers: she told David Garnett in 1925 that when readers praised the manuscript as charming ' $I$ felt as though I had tried to make a sword only to be told what a pretty pattern there was on the blade' (Garnett, R., 1994, p.26). This seems to me nearer the truth than her later condescension. Lolly Willowes is a passionate and angry book as well as a coolly charming one, and it has some of the enduring romantic appeal of stories like Jane Eyre and Rebecca, where the worm turns and the put-upon heroine comes into her own. The book gives powerful life and shape to a story of self-disclosure: Laura's misery is evoked mainly through her silent passivity, and her courage in acknowledging the fearful truth of her own nature is described as an absolution, a release from the sin of her previous self-suppression: 'With every breath she drew, the scent of the cowslips flowed in and absolved her' (p. 149).

That formulation gives nature an active role, aligning it with the devil's work and the realisations of the "true Laura'. 'She had known where to turn' (p.175), the narrator tells us, in an exhilarating declaration of faith in the inner life and its impulsions. Warner is a materialist author as well as here a romantic, so this knowledge of Laura's entails going to a map shop, being referred to a more specialised map shop, and doing some research before knowing what to do, and 'where', in a literal sense, 'to turn'. The decisive clarity of her move puts me in 
mind of Eve Kosofsky Sedgwick's fine comment on 'an amazing tenderness of affirmation' in 'Paul's Case', Willa Cather's dark story of ill-fated homosexual selfdiscovery: 'How common is it, in a fictional tradition ruled by le mensonge romantique, for a powerfully desiring character to get the thing that he desires, and to learn immediately that he was right - that what he wanted really is the thing that will make him happy?' (Sedgwick, 1994, p.170). What Laura thought she wanted, imagining it from London, really was the thing that would fulfil her nature.

The narrative takes Laura's part in her turn to Great Mop. Like its heroine, the book embraces a fantasy that hadn't seemed to be its ordained destination. Both Laura Willowes and Lolly Willowes deviate from their expected courses. To that extent, we might say it is a queer book as well as a book about queerness. Whereas 'we stay where we are' is the 'statement of the Willowes mind' (p.71), Laura leaves her family in London and remakes her life. The book likewise declines to stay where it was, leaving off its realistic mode and remaking itself as fantasy. It moves from being a dynastic family saga, the world perhaps of John Galsworthy, to a more elusive and mixed genre in Great Mop - partly, as Ray Russell proposed in this journal (Russell, 2001, pp.25-31) to the supernaturalist world of Arthur Machen; partly, as J.I.M. Stewart suggested in 1978, to the cool cultural investigation of Satan to be found in Shaw's Devil's Disciple (1897), or again, as Gay Wachman suggests, to Vernon Lee's Satan the Waster (1915); and partly it may look even further back to Shaw's and Lee's and Warner's Enlightenment forebears, to the philosophical contes and dialogues of Diderot or Voltaire, or to Goethe's Conversations with Eckermann, which Warner was reading in 1925 (letter to Garnett, 16 June 1925, in Maxwell, 1982, pp.6-7) and which gets a name-check in the book (Warner, 1926, p.234). The change of mode is itself a liberation, a freedom from anger about the oppression and suppression visited on Laura, and a freedom from further attention to her hateful brother. 
Henry is a pompous bully and not especially bright, but there will always be a plentiful stock of Henrys in the world and the book implies that he's not worth the energy of her continuing anger. The London Willoweses hardly get a mention in the third section of the book, and Warner chooses not to conclude dynastically by looking to the furtherance of the family line: indeed the book explicitly sets this continuation aside as it sends Titus and his new fiancée away from Great Mop. It ends instead by bringing Laura out from her taciturnity to give her by far her longest utterance in the book (pp.234-9). This is a spectacularly long speech about witches and witchcraft, in which for the first time she has the transgressive selfpossession to speak as eloquent commentator on her own life - an exhilarating, dissident conclusion. By this time she is what she damned well is.

\section{NOTES}

1. See especially Lucas (2000), pp.7-10, on 'Cottage Mantelpiece'.

2. The idea of 'perverse reading' is taken from Bonnie Zimmerman.

3. Garrity is here continuing Laura's initial mistake of thinking the masked young man at the Sabbath to be really Satan.

4. Is it coincidence that Warner's difficult friend Stephen Tomlin was born in 1901, as Titus is said to be? His métier, too, was sculpture. Claire Harman's biography of Warner describes 'Tommy' as 'sexually ambivalent' and notes that 'he decided to chuck up his degree [at Oxford] and become a sculptor, a decision which met with fierce opposition at home' $(1989$, p. 44). The two were close friends in the early $1920 \mathrm{~s}$, and it was Tommy who introduced Sylvia to David Garnett and the Powyses, so he was a crucial figure in her life. But Tommy became less of a friend, and came to make her the recipient of his unwanted calls when he was depressed, on which occasions he would spend the whole time, partly prompted by his psychoanalytic treatment, talking about himself. Virginia Woolf, who sat for him, 'took a shudder 
at the impact of his neurotic clinging persistency' (see Woolf's Diary, vol. 5, p.47, cited by Harman, 1989, p. 69) and ended the sittings. Harman tells us that 'In 1926 there was a crisis between Sylvia and Tommy and an irrevocable, deeply wounding break. The cause is unknown...' (1989, p. 68). May it have been related to Tommy's seeing in Titus an unflattering portrait of himself? The eight-year age-gap between Sylvia and Tommy would be reflected and hardened into the generation gap between aunt and nephew in the book. Like Titus, Tommy decides to enter a socially advantageous marriage (to Julia Strachey, Lytton's niece). Warner's letters to Maxwell and others point out that Titus's views of Fuseli were not her own but 'what would come naturally from a clever young man in the 1920s' (Steinman, 2001, p. 171), emphasising the author's distance from her character both in gender and years. And indeed Lolly Willowes treats Titus harshly, not allowing him a chance to reform or see his aunt's point of view.

The Billy Williams figure in 'A Night Out' (collected in A Garland of Straw, 1943) is said by Claire Harman to be modelled on Tomlin. Billy is less languid than Titus, but still his ruralist enthusiasms and his masculine bossiness in that story are Titus-like. But the affectionate tone of this later story, its pleasure in nerve and adventure, and its trust that impetuous actions can lead somewhere good, might be seen as making amends for the bad blood between them, six years after Tomlin's early death.

5. Rosemary Sykes investigates some of the tensions and contradictions in 'the house of Willowes' in 'The Willowes Pattern', The Journal of the Sylvia Townsend Warner Society (2001), pp. 1-17.

6. The Woolfs and the Stracheys were at the heart of this, with the first translations of Freud by James Strachey published by Leonard and Virginia Woolf's Hogarth Press.

7. Wendy Mulford, This Narrow Place (London: Pandora, 1988), p. 15. Mulford on page 251 cites the quotation as coming from 'On Being a Lily' in Scenes of Childhood, 
p. 142, but it is not to be found there and I haven't yet been able to trace it.

8. A later Warner 'mincing', from 'Truth in the Cup', supports the connotation: 'Light as a wafer, pale as gin, a queer, and probably dauntless as a lion, Colin Dudevant, the hotel proprietor, was now mincing among his guests...' (Warner, 1971, p. 13) This 'queer' is given so glintingly strange a sequence of attributes and similes that it reads like a tribute.

9. Laura finds places which speak to her buried life in London as well as Great Mop: burial grounds, churches of many denominations, railway goods yards, fox-haunted city parks and paths. The shop where she buys chrysanthemums is a real shop but a magic one too, in the tradition of Balzac and Pushkin. She finds it when 'for diversion she thought she would take a circuitous route' (p.82), via Holland Park, Bayswater Synagogue and Moscow Road, the very names bringing otherworldly touches of the Netherlands, Jewry and Russia into the English metropolitan scene. Modern change does not eradicate deeper permanences: 'Once a wood, always a wood', Satan tells her (p.230).

10. Warner herself was nine or ten years old at the time of these processions. Were they discussed at family mealtimes?

11. The original ending of the book is published in The Journal of the STW Society (2001), pp. 32-34.

12. During the war Warner was called upon for 'employment of national importance', and complained that this wouldn't have happened if she had been married: 'But to be femme sole, and self supporting, that hands you over, no more claim to consideration than a biscuit' (to Nancy Cunard, 28 April 1944 in Maxwell, 1982, p.84). Mr Wolf-Saunders' argument could in fact lead to an opposite conclusion from the one he seems to urge. Laura as feme sole had the disposition of her own income and movements, but unwisely trusted the former to the head of the family. 


\section{WORKS CITED}

BEER, G. (2004) "Sylvia Townsend Warner: "The Centrifugal Kick", in The Journal of the Sylvia Townsend Warner Society (2004), pp. 18-31, reprinted from Women Writers of the 1930s: Gender, Politics, History. Ed. Maroula Joannou. Edinburgh, Edinburgh University. Press, 1999.

BLAKE, W. (1977) 'The Second Memorable Fancy' from The Marriage of Heaven and Hell [c.1790]. Ed. Alicia Ostriker. London, Penguin Classics

CATHER, W. (1996) 'Paul's Case' and Other Writings. [1905]. New York, Dover.

GARNETT, R. Ed. (1994) Sylvia and David. The Townsend Warner/Garnett Letters. London, SinclairStevenson.

GARRITY, J. (2003) Chapter 3, 'Encoding bi-location: Sylvia Townsend Warner and the primitive erotics of sapphic dissimulation' in Step-Daughters of England: British Women Modernists and the National Imaginary. Manchester, Manchester University Press, pp. 140-187. HALL, R. (1928) The Well of Loneliness. London, Jonathan Cape.

HARMAN, C. (1989) Sylvia Townsend Warner. A Biography. London, Chatto \& Windus.

JACOBS, M. (2006) 'Sylvia Townsend Warner and the Politics of the English pastoral 1925-1934' in Critical Essays on Sylvia Townsend Warner, English Novelist. Eds. Gill Davies, David Malcolm and John Simons. Lampeter, Edwin Mellen Press, pp.61-82.

LONDON, J. (1999), People of the Abyss [1903] in The Metropolitan Poor. Semi-Factual Accounts 1795-1910 Vol. 3 People of the Abyss, 1885-1910. Ed.Marriott and Matsumura. London, Pickering and Chatto. 6 vols.

LUCAS, J. (2000) 'Sylvia Townsend Warner as Poet' in The Journal of the Sylvia Townsend Warner Society (2000), pp. I-16.

MAXWELL, W. Ed. (1982) Sylvia Townsend Warner.

Letters. London, Chatto \& Windus. 
MULFORD, W. (1988) This Narrow Place, Sylvia Townsend Warner and Valentine Ackland: Life, Letters and Politics, 1930-1951. London, Pandora.

RUSSELL, R.B. (2001), 'Alternative Lives in Sylvia Townsend Warner's Lolly Willowes and Arthur Machen's "A Fragment of Life" in The Journal of the Sylvia Townsend Warner Society, (2001) pp.25-31

SEDGWICK, E.K. (1994) Tendencies. London, Routledge.

STEINMAN, M. Ed. (2001) The Element of Lavishness. Letters of Sylvia Townsend Warner and William Maxwell 1938-1978. Washington, D.C., Counterpoint.

SYKES, R. (2001) 'The Willowes Pattern' in The Journal of the Sylvia Townsend Warner Society, (2001) pp.1-17

WACHMAN, G. (2001) Lesbian Empire: Radical Crosswriting in the Twenties. Piscataway, Rutgers University Press.

WARNER, S.T. (1926) Lolly Willowes or The Loving Huntsman. London, Chatto \& Windus.

(1931) Opus 7. London, Chatto \& Windus. Windus.

(1936) Summer Will Show. London, Chatto \&

(1938) After the Death of Don Juan. London, Chatto \& Windus. Windus.

(1943), A Garland of Straw. London, Chatto \& Chatto \& Windus.

(1971) The Innocent and the Guilty. London,

(1988) Selected Stories. Eds Susanna Pinney and William Maxwell. London, Chatto \& Windus.

(2001) The Music at Long Verney. Ed. Michael Steinman. London, Harvill Press.

WOOLF, V. (1925) Mrs Dalloway. London, Hogarth Press.

Press.

(1929) A Room of One's Own. London, Hogarth (1980) The Diary of Virginia Woolf, Vol. 3 19251950. Ed. A.O. Bell with A. McNeillie. London, Hogarth Press. 5 vols. (1977-1984) 